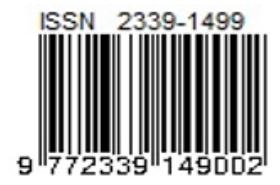

\title{
Pemilihan Supplier Rubber Parts Dengan Metode Analytical Hierarchy Process Di PT.XYZ
}

\author{
Dino Rimantho', Fathurohman², Bambang Cahyadi ${ }^{3}$, Sodikun ${ }^{4}$ \\ 1,2,3, Fakultas Teknik, Jurusan Teknik Industri, Universitas Pancasila \\ Jl. Srengseng Sawah, Jagakarsa - Jakarta Selatan, DKI Jakarta 12640 \\ Email: dino.rimantho@univpancasila.ac.id
}

\begin{abstract}
In order to facing an increasingly competitive world of manufacturing industry, it is necessary to select appropriate suppliers to produce quality products at competitive prices. This requires producers to make efficiency. Supplier selection is one way to make efficiency by considering several factors. In this research, the ideal supplier selection is made on rubber component using AHP (Analytic Hierarchy Process) method with three criteria factors that are considered important by the company such as, production factor $(48 \%)$, quality $(40 \%)$, and price $(12 \%)$. Furthermore, this study shows The TRHI as suppliers with the largest value of $51.6 \%$ compared to other suppliers such as IKP (24.8\%) and IRC (23.6\%).
\end{abstract}

Keywords: AHP, Competitive, Efficiency, Rubber, Supplier

\begin{abstract}
Abstrak
Dalam menghadapi dunia industri manufaktur yang semakin kompetitif, diperlukan pemilihan supplier yang tepat guna untuk menghasilkan produk yang berkualitas dengan harga yang bersaing. Hal ini menuntut para produsen untuk melakukan efisiensi. Pemilihan supplier merupakan salah satu cara untuk melakukan efisiensi dengan mempertimbangkan beberapa kepentingan. Pada penelitian ini dilakukan pemilihan supplier yang ideal pada komponen rubber dengan menggunakan metode AHP (Analytic Hierarchy Process) dengan tiga faktor kriteria yang dianggap penting oleh perusahaan yaitu faktor produksi $(48 \%)$, kualitas(40\%), dan harga(12\%). Lebih lanjut, penelitian ini menunjukkan supplier TRHI dengan bobot nilai terbesar $51,6 \%$ dibanding supplier lainnya seperti $\operatorname{IKP}(24,8 \%)$ dan $\operatorname{IRC}(23,6 \%)$.
\end{abstract}

\section{Kata kunci: AHP, Kompetitif, Efisiensi, Rubber, Supplier}

\section{Pendahuluan}

Supply chain merupakan suatu rangkaian proses aliran yang terjadi di dalam dan diantara tahapan supply chain yang berbeda dan berkombinasi untuk memenuhi kebutuhan pelanggan atas suatu produk (Chopra dan Meindl, 2001). Di dalam supply chain banyak bagian yang terlibat di dalamnya, baik secara langsung ataupun tidak langsung dalam memenuhi permintaan pelanggan. Tidak hanya hubungan antara sales dan customer, tetapi juga hubungan antara bagian produksi, warehouse, supplier, dealer, dan masih banyak bagian lain yang terkait.

Sebagai perusahaan Agen Tunggal Pemegang Merk (ATPM) yang melakukan perakitan mobil di Indonesia, PT. XYZ mempunyai peranan penting dalam pemilihan supplier lokal, sebagai contoh salah satu model kendaraan mempunyai $85 \%$ kandungan lokal di Indonesia (data PT. XYZ) dan sisanya supply dari Jepang, Thailand, dan India. Kondisi pasar yang kompetetitif, menuntut harga jual kendaraan terjangkau untuk masyarakat. Hal ini berdampak pada penekanan biaya baik di dalam perusahaan ATPM maupun supplier.

Pemilihan supplier menjadi bagian yang harus terkelola dengan baik dan terpancang di supply chain, hubungan ini akan berpengaruh pada daya saing seluruh aktivitas supply chain. Karena itu, permasalahan pemilihan supplier menjadi salah satu isu penting untuk 
pembentukan efektivitas supply chain system. Pemilihan supplier tidak hanya melihat pada harga. Banyak kriteria yang perlu diperhatikan, seperti kualitas yang baik, pengiriman tepat waktu sampai dengan kapasitas produksi yang memadai (Singh et al, 2012). Namun kondisi perusahan yang diteliti hanya berdasarkan kriteria harga saja, adapun kriteria lain seperti quality, safety, dan environment kurang diperhatikan. Dan hanya berdasarkan pengalaman dari buyer dan management. Hal ini berdampak di aktivitas selanjutnya akan terjadi masalah.

Banyaknya supplier yang bergerak di manufaktur, perusahaan PT. XYZ sebagai Agen Tunggal Pemegang Merk (ATPM) dihadapkan pada beberapa alternatif supplier, dimana setiap supplier memiliki kelebihan dan kekurangan masing-masing. Hal ini menuntut kejelian ATPM untuk dapat menganalisa supplier mana yang tepat dan layak untuk diprioritaskan menjadi mitra bisnis.

Pemilihan supplier merupakan proses yang panjang. supplier dievaluasi dalam beberapa kriteria seperti biaya, pengiriman, kualitas dan lain-lain. Pada saat melakukan evaluasi dari beberapa kriteria sering terjadi trade off seperti adanya supplier yang menawarkan produk dengan kualitas yang bagus tetapi pengirimannya tidak pasti (Singh et al, 2012). Semakin banyaknya kriteria yang diinginkan perusahaan untuk memilih supplier membuat masalah semakin rumit, oleh karena itu diperlukan suatu teknik pengambilan keputusan dalam pemilihan supplier.

Salah satu metode yang digunakan dalam pengambilan keputusan adalah metode Analytic Network Process (ANP) dapat diusulkan sebagai alternatif metode pengambilan keputusan yang lebih terstruktur. Studi yang dilakukan oleh Alfian dkk (2013) menerapkan metode ANP dalam memilih supplier yang memasok kertas. Lebih lanjut, penelitian tersebut menunjukkan keterkaitan setiap faktor dalam pengambilan keputusan dan menghasilkan bobot nilai prioritas pada seluruh faktor dalam pengambilan keputusan.

Selain metode ANP, terdapat metode lainnya yang dapat digunakan dalam pengambilan keputusan, yaitu AHP (Analytic hierarchy proces). Teknik ini merupakan metode yang digunakan dalam proses pengambilan keputusan suatu masalah kompleks dengan aspek atau kriteria yang dipertimbangkan cukup banyak (Saaty, 1980). AHP digunakan karena konsepnya sederhana, mudah dipahami, dan memiliki kemampuan untuk mengukur kinerja yang berhubungan dari alternatif-alternatif supplier dalam bentuk matematis yang sederhana.

\section{Kajian Pustaka}

\section{Supply Chain Management}

Supply Chain Management (SCM) adalah filosofi manajemen yang terus menerus mencari sumber-sumber fungsi bisnis yang kompeten untuk digabungkan baik dalam perusahaan maupun di luar perusahaan seperti mitra bisnis yang berada dalam satu supply chain untuk memasuki sistem supply yang berdaya saing tinggi dan memperhatikan kebutuhan pelanggan, yang berfokus pada pengembangan solusi inovatif dan sinkronisasi aliran produk, jasa, dan informasi untuk menciptakan sumber nilai pelanggan (customer value) secara unik. Dengan memanfaatkan SCM, suatu perusahaan akan mendapatkan manfaat (Pujawan, 2005).

\section{Analytic Hierarchy Process (AHP)}

Metode AHP merupakan proses "rasionalitas sistemik". Lebih lanjut, metode AHP memungkinkan untuk mempertimbangkan suatu persoalan sebagai satu keseluruhan dan mengkaji interaksi serempak dari berbagai komponen yang disusun secara berjenjang (hirarkis) sehingga mudah dipahami dan dianalisis. AHP dapat digunakan untuk merangsang timbulnya gagasan untuk melaksanakan tindakan kreatif, dan untuk mengevaluasi keefektifan tindakan tersebut Selain itu, untuk membantu para pemimpin menetapkan informasi apa yang patut dikumpulkan guna mengevaluasi pengaruh faktor-faktor relevan dalam situasi kompleks. AHP juga dapat melacak ketidakkonsistenan dalam pertimbangan dan preferensi peserta, sehingga para pemimpin mampu menilai mutu pengetahuan para pembantu mereka dan pemantapan pemecahan itu (Saaty dan Vargas, 1993).

Menurut Suryadi dan Ramdhani (2002,h.131) kelebihan AHP dibanding metode lain, diantaranya sebagai berikut. 1. Struktur yang berhirarki, sebagai konsekuensi dari kriteria yang dipilih, sampai pada subkriteria yang paling dalam. Kriteria menjadi level kedua setelah sasaran (goal), yakni pemilihan 
database. Penentuan kriteria dilakukan berdasarkan keputusan pimpinan atas masukan dari kepala divisi IT. 2. Memperhitungkan validitas sampai dengan batas toleransi inkonsistensi berbagai kriteria dan alternatif yang dipilih oleh para pengambil keputusan. Konsistensi setiap level diperiksa, baik level kriteria (kriteria pemilihan) maupun level alternatif (perangkat lunak database). 3 . Memperhitungkan daya tahan atau ketahanan output analisis sensitivitas pengambilan keputusan. Selain itu, AHP mempunyai kemampuan untuk memecahkan masalah yang multiobjektif dan multikriteria yang berdasar pada perbandingan preferensi dari setiap elemen dalam hirarki. Jadi, model ini merupakan suatu model pengambilan keputusan yang komprehensif

Penerapan AHP telah dilakukan di sejumlah penelitian. Sebagai contoh, di Amerika Serikat dilakukan penerapan metode AHP dalam pengelolaan merkuri (Randall et al., 2004). Implementasi metode AHP dalam pengambilan keputusan pencegahan kecelakaan kerja pada pekerja pengumpul sampah (Rimantho dan Cahyadi, 2016). Selanjutnya, studi yang dilakukan oleh Wang et al., (2009) mengaplikasikan metode AHP dalam rangka untuk mengurangi kompleksitas sistem pemilihan pengelolaan limbah padat. Selain itu, Rimantho dkk, (2015) mengusulkan metode AHP sebagai metodologi yang dapat diadopsi untuk menilai berbagai alternatif daur ulang limbah elektronik. Metode AHP juga mampu menyelesaikan masalah pada kalibarasi peralatan di industri farmasi (Rimantho, dkk., 2017).

\section{Prisip Pokok AHP}

Dalam penggunaannya, AHP mengenal 3 (tiga) prinsip pokok (Saaty, 1980), yaitu :

a. Penyusunan hirarki.

Penyusunan realitas yang kompleks kedalam bagian yang menjadi elemen pokoknya secara hierarkis (berjenjang).

b. Penentuan prioritas.

Persepsi hubungan antara hal-hal yang diamati,membandingkan hal yang serupa berdasarkan kriteria tertentu, dan membedakan kedua anggota pasangan itu dengan menimbang intensitas preferensi mereka terhadap hal yang satu dibandingkan dengan yang lainnya. Hasil dari proses pembedaan ini adalah suatu vektor prioritas, atau relatif pentingnya elemen terhadap setiap sifat. Prioritas ini ditentukan berdasarkan pandangan para pakar atau pihak-pihak terkait yang berkompeten terhadap pengambilan keputusan.

c. Konsistensi logis.

Konsistensi berarti dua hal. Yang pertama, bahwa pemikiran atau obyek yang serupa dikelompokan menurut homogenitas dan relevansinya. Yang kedua adalah intensitas relasi antar gagasan atau antar obyek yang didasarkan pada satu kriteria tertentu, saling membenarkan secara logis. Proses ini dengan jelas menunjukan bahwa segi kuantitatif merupakan dasar untuk mengambil keputusan yang sehat dalam situasi kompleks, dimana kita perlu menetapkan prioritas dan melakukan perimbangan.

\section{Prosedur AHP}

Langkah-langkah atau prosedur yang harus dilakukan dalam metode AHP untuk pemecahan suatu masalah, yaitu :

1. Definisikan persoalan dan rincian pemecahan yang diinginkan

2. Struktur hirarki dari sudut pandang menyeluruh

3. Buatlah sebuah matrik banding berpasangan untuk kontribusi atau pengaruh setiap elemen yang relevan atas setiap kriteria yang berpengaruh yang berada setingkat diatasnya.

4. Dapatkan semua pertimbangan yang diperlukan untuk mengembangkan perangkat matriks dilangkah 3.

5. Setelah mengumpulkan semua data banding berpasangan, prioritas dicari dan konsistensi diuji.

6. Laksanakan langkah 3, 4 dan 5 untuk semua tingkat dan gugusan dalam hierarki itu.

7. Gunakan komposisi secara hierarkis (sintesis) untuk membobotkan vektor-vektor prioritas itu dengan bobot kriteria-kriteria

8. Evaluasi konsistensi untuk seluruh hieraraki.

\section{Penyusunan Struktur Hirarki}

Hierarki merupakan alat mendasar dari pikiran manusia, melibatkan identifikasi elemen-elemen suatu persoalan, mengelompokan elemen-elemen itu kedalam beberapa kumpulan yang homogen, dan menata kumpulan-kumpulan ini pada tingkat- 
tingkat yang berbeda. Pada dasarnya ada dua macam hirarki, yaitu hirarki struktural dan hirarki fungsional. Pada hirarki struktural, sistem yang kompleks disusun ke dalam komponenkomponen pokoknya dengan urutan menurun menurut sifat struktural mereka. Sedangkan, hirarki fungsional menguraikan sistem yang kompleks menjadi elemen-elemen pokoknya menurut hubungan esensial mereka.

Penyusunan prioritas dilakukan dengan mencari bobot relatif antar elemen sehingga diketahui tingkat kepentingan (preferensi) dari tiap elemen dalam permasalahan secara keseluruhan. Langkah pertama dalam menentukan susunan prioritas elemen adalah dengan menyusun perbandingan berpasangan, yaitu membandingkan dalam bentuk berpasangan seluruh elemen untuk setiap sub sistem hirarki dan kemudian ditransformasikan dalam bentuk matriks untuk analisis numerik.

Misalkan terdapat suatu sub sistem hirarki dengan satu kriteria $C$ dan sejumlah $n$ elemen di bawahnya, $A_{1}$ sampai $A_{n}$, seperti terlihat pada gambar 1.

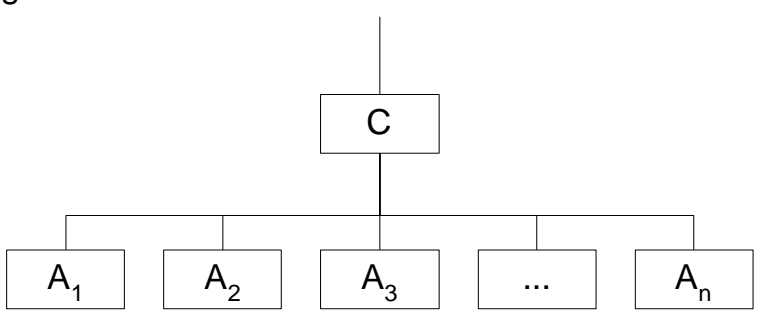

Gambar 1. Sub Sistem Hirarki Sumber: (Saaty, 1993)

Perbandingan antar elemen tersebut dibuat dalam bentuk matriks $\mathrm{n} \times \mathrm{n}$ atau matriks perbandingan berpasangan.

Nilai $a_{i j}$ adalah nilai perbandingan elemen $A_{i}$ terhadap elemen $A_{j} y a n g$ menyatakan hubungan : seberapa jauh tingkat kepentingan $A_{i}$ bila dibandingkan dengan $A_{j}$, seberapa banyak kontribusi $A_{i}$ terhadap kriteria $C$ dibandingkan dengan $A_{j}$, seberapa jauh dominasi Aidibandingkan dengan $A_{j}$, seberapa banyak sifat kriteria $C$ terdapat pada $\mathrm{Ai}$ dibandingkan dengan $\mathrm{Aj}$ (ihat tabel 1).

Tabel 1. Matriks Perbandingan Berpasangan

\begin{tabular}{|l|l|l|l|l|l|}
\hline $\mathrm{C}$ & $\mathrm{A}_{1}$ & $\mathrm{~A}_{2}$ & $\mathrm{~A}_{3}$ & $\ldots$. & $\mathrm{A}_{n}$ \\
\hline $\mathrm{A}_{1}$ & $\mathrm{a}_{11}$ & $\mathrm{a}_{12}$ & $\mathrm{a}_{13}$ & $\ldots .$. & $\mathrm{a}_{1 n}$ \\
\hline $\mathrm{A}_{2}$ & $\mathrm{a}_{21}$ & $\mathrm{a}_{22}$ & $\mathrm{a}_{23}$ & $\ldots \ldots$ & $\mathrm{a}_{2 n}$ \\
\hline $\mathrm{A}_{3}$ & $\mathrm{a}_{31}$ & $\mathrm{a}_{32}$ & $\mathrm{a}_{33}$ & $\ldots \ldots$ & $\mathrm{A}_{3 n}$ \\
\hline$\ldots$. & $\ldots$. & $\ldots$. & $\ldots$. & $\ldots$. & $\ldots$. \\
\hline$A_{n}$ & $\mathrm{a}_{n 1}$ & $\mathrm{a}_{n 2}$ & $\mathrm{a}_{n 3}$ & $\ldots$. & $\mathrm{a}_{n n}$ \\
\hline
\end{tabular}

Sumber : Saaty (1993)
Nilai numerik yang dikenakan untuk perbandingan di atas diperoleh dari skala perbandingan yang dibuat oleh Saaty (1993).

Tabel 2. Skala Perbandingan Nilai

\begin{tabular}{|c|c|c|}
\hline $\begin{array}{l}\text { Tingkat } \\
\text { Kepentingan }\end{array}$ & Definisi & Keterangan \\
\hline 1 & $\begin{array}{l}\text { Sama } \\
\text { penting }\end{array}$ & $\begin{array}{lr}\text { Kedua } & \text { elemen } \\
\text { mempunyai } & \\
\text { pengaruh } & \text { yang } \\
\text { sama } & \end{array}$ \\
\hline 3 & $\begin{array}{l}\text { Sedikit } \\
\text { lebih } \\
\text { penting }\end{array}$ & $\begin{array}{l}\text { Pengalaman dan } \\
\text { penilaian sedikit } \\
\text { lebih memihak ke } \\
\text { satu elemen } \\
\text { dibandingkan } \\
\text { dengan } \\
\text { pasangannya }\end{array}$ \\
\hline 5 & $\begin{array}{l}\text { Lebih } \\
\text { penting }\end{array}$ & $\begin{array}{l}\text { Pengalaman dan } \\
\text { penilaian sangat } \\
\text { memihak ke satu } \\
\text { elemen } \\
\text { dibandingkan } \\
\text { dengan } \\
\text { pasangannya }\end{array}$ \\
\hline 7 & $\begin{array}{l}\text { Sangat } \\
\text { penting }\end{array}$ & $\begin{array}{l}\text { Satu elemen sangat } \\
\text { disukai dan secara } \\
\text { praktis dominasinya } \\
\text { sangat nyata } \\
\text { dibandingkan } \\
\text { dengan elemen } \\
\text { pasangannya }\end{array}$ \\
\hline 9 & $\begin{array}{l}\text { Mutlak } \\
\text { lebih } \\
\text { penting }\end{array}$ & $\begin{array}{l}\text { Satu elemen terbukti } \\
\text { mutlak lebih disukai } \\
\text { dibandingkan } \\
\text { dengan } \\
\text { pasangannya pada } \\
\text { tingkat keyakinan } \\
\text { tertinggi }\end{array}$ \\
\hline $2,4,6,8$ & $\begin{array}{l}\text { Nilai } \\
\text { tengah }\end{array}$ & $\begin{array}{lr}\text { Diberikan } & \text { bila } \\
\text { terdapat } & \text { keraguan } \\
\text { penilaian } & \text { Antara } \\
\text { penilaian } & \text { yang } \\
\text { berdekatan } & \end{array}$ \\
\hline Kebali & & \\
\hline
\end{tabular}

Sumber : Saaty (1993)

\section{Penilaian Perbandingan Multi Partisipan}

Penilaian yang dilakukan oleh banyak partisipan akan menghasilkan pendapat yang berbeda satu sama lain. AHP hanya membutuhkan satu jawaban untuk satu matriks perbandingan. Oleh karena itu, Saaty (1993) memberikan metode perataan jawaban partisipan dengan Geometric Mean. Geometric Mean Theory menyatakan bahwa jika terdapat $\mathrm{n}$ partisipan melakukan perbandingan berpasangan, maka terdapat $\mathrm{n}$ jawaban (nilai) numerik untuk setiap pasangan. Untuk mendapatkan satu nilai tertentu dari semua nilai tersebut, masing-masing nilai harus dikalikan satu sama lain, kemudian hasil perkalian dipangkatkan dengan $1 / n$. Secara matematis 
dapat dituliskan seperti persamaan berikut :

$$
a_{i j}=\left(z_{1} \times z_{2} \times z_{3} \times \ldots \times z_{n}\right)^{1 / n} \quad \text { Pers. } 1
$$

Dimana :

$a_{i j}$ adalah nilai rata-rata perbandingan antara $A_{i}$ dengan $A_{j}$ untuk $n$ partisipan.

$z_{i}$ adalah nilai perbandingan antara kriteria $A_{i}$ dengan $A_{j}$ partisipan ke-i.

$\mathrm{n}$ adalah jumlah partisipan.

\section{Pengujian Konsistensi}

Dalam persoalan pengambilan keputusan penting untuk mengetahui betapa baiknya konsistensi pengambil keputusan. Semakin banyak faktor yang harusdipertimbangkan, semakin sukar untuk mempertahankan konsistensi, ditambah lagi adanya intuisi dan faktor-faktor lain yang membuat orang mungkin menyimpang dari kekonsistensian.

Meskipun demikian sampai kadar tertentu perlu diperoleh hasil-hasil yang valid dalam dunia nyata. Saaty mengajukan indeks konsistensi untuk mengukur seberapa besar konsistensi pengambil keputusan dalam membandingkan elemen-elemen dalam matrik penilaian. Selanjutnya indeks konsisten ditransfer sesuai dengan orde atau ukuran matrik menjadi suatu rasio konsistensi. Rasio konsistensi harus $\leq 10 \%$, jika tidak pertimbangan yang telah dibuat mungkin akan acak dan perlu diperbaiki.

Pada matriks konsisten, secara praktis $\lambda \max =n$, sedangkan pada matriks tak konsisten, setiap variasi dari aij akan membawa perubahan pada nilai $\lambda$ max. Deviasi $\lambda$ max dari $\mathrm{n}$ merupakan suatu parameter Consistency Index $(\mathrm{Cl})$, yang dinyatakan dengan:

$$
\mathrm{CI}=\frac{\lambda_{\max }-\mathrm{n}}{\mathrm{n}-1}
$$

Pers. 2

Dari matriks random tersebut didapatkan juga nilai Consistency Index, yang disebut dengan Random Index (RI).

Dengan membandingkan CI dan RI maka didapatkan patokan untuk menentukan tingkat konsistensi suatu matriks, yang disebut dengan Consistency Ratio (CR). Suatu matriks perbandingan adalah dinyatakan konsisten jika nilai CR tidak lebih dari 0,10 (CR $\leq 0,10)$.

$$
\mathrm{CR}=\frac{\mathrm{CI}(\text { Consistency Ratio })}{\mathrm{RI}(\text { Random Index })}
$$

Pers. 3

\section{Pengujian Konsistensi Hirarki}

Prinsipnya adalah dengan mengalikan semua nilai Consistency Index (CI) dengan bobot suatu kriteria yang menjadi acuan pada suatu matriks perbandingan berpasangan dan kemudian menjumlahkannya. Jumlah tersebut dibandingkan dengan nilai yang didapat dengan cara sama tetapi untuk suatu matriks random.

Tabel 3. Nilai Random Indeks

\begin{tabular}{|c|c|}
\hline Orde Matriks & Random Indeks \\
\hline 1 & 0,00 \\
\hline 2 & 0,00 \\
\hline 3 & 0,58 \\
\hline 4 & 0,90 \\
\hline 5 & 1,12 \\
\hline 6 & 1,24 \\
\hline 7 & 1,32 \\
\hline 8 & 1,41 \\
\hline 9 & 1,45 \\
\hline 10 & 1,49 \\
\hline \multicolumn{2}{|c|}{ Sumber : Saaty (1993) }
\end{tabular}

Hasil akhirnya berupa suatu parameter yang disebut dengan Consistency Ratio of Hierarchy ( $C R H$ ), dengan persamaan sebagai berikut :

$\mathrm{CRH}=\frac{\mathrm{CIH}}{\mathrm{RIH}}=\frac{\sum(\mathrm{CI} \times \text { Bobot Kriteria })}{\sum(\mathrm{RI} \times \text { Bobot Kriteria })}$

Pers. 4

\section{Analisis Sensitivitas}

Analisis sensitivitas dilakukan pada bobot prioritas dari kriteria keputusan, yang dapat terjadi karena adanya perubahan kebijaksanaan sehingga pembuat keputusan mengubah penilaiannya. Analisis sensitivitas dapat memprediksi keadaan apabila terjadi perubahan yang cukup besar. Misalnya terjadi perubahan penilaian bobot prioritas karena adanya perubahan kebijaksanaan sehingga akan menyebabkan berubahnya urutan prioritas alternatif dan berubah juga tindakan yang perlu dilakukan.

\section{METODE}

Penelitian ini dilakukan di PT.XYZ sebagai perusahaan ATPM kendaraan roda empat. Objek penelitian dalam pembahasan ini adalah pemilihan supplier pada rubber part. Data diambil dengan proses pemungutan suara (kuesioner) kepada kepala departemen dan staf ahli di divisi purchasing, dimana pemilihan responden sebagai informan kunci didasarkan pada pengalaman responden dalam mengambil 
keputusan. Pengumpulan data pemilihan calon supplier dilakukan melalui beberapa tahapan, yaitu:

a. Penyusuan kuesioner tahap 1, dalam tahapan ini dilakukan pengumpulan beberapa kriteria-kriteria yang mempengaruhi keputusan pemilihan supplier dari hasil studi literatur, kemudian dipilih kriteria yang dianggap sangat penting untuk menentukan faktor kriteria dalam perhitungan AHP dengan cara menyebar kuesioner ke responden, responden yang dipilih pada tahap ini adalah manajer yang sudah berpengalaman kerja diatas sepuluh tahun.

b. Penentuan kriteria pemilihan supplier, tahap ini adalah hasil dari tahap 1 yaitu kriteria-kriteria apa saja yang dianggap penting dalam penentuan pemilihan supplier.

c. Penyusunan kuesioner tahap 2, pada tahap ini dilakukan penyebaran kuesioner penilaian pembobotan terhadap kriteriakriteria yang merupakan hasil dari kuesioner tahap 1, responden yang dipilih adalah staf ahli yang sudah bekerja diatas dua tahun.

d. Pengolahan data pada kuesiner tahap 2, pada tahap ini dilakukan pengolahan data dan analisis dari hasil kuesioner tahap 2 dengan menggunakan perhitungan AHP.

\section{ANALISIS DATA}

Pada kuesioner tahap 1, diambil 25 kriteria pemilihan supplier dari hasil studi literatur, kemudian disebar kuesioner tahap 1 dengan jumlah 3 responden. Dari hasil kuesioner tersebut dipilih kriteria dengan nilai rata-rata diatas 4. Berikut adalah hasil kuesioner tahap 1

Tabel 4. Kriteria hasil kuesioner tahap 1

\begin{tabular}{|l|l|l|}
\hline No & Kriteria pemilihan supplier & Kategori \\
\hline 1 & Harga produk sesuai target & Harga \\
\hline 2 & $\begin{array}{l}\text { Biaya investasi tooling sesuai } \\
\text { target }\end{array}$ & Harga \\
\hline 3 & Ketepatan waktu pengiriman & Kualitas \\
\hline 4 & $\begin{array}{l}\text { Ketepatan jumlah pengiriman } \\
\text { Krosentase produk NG } \\
\text { terhadap jumlah produksi }\end{array}$ & Kualitas \\
\hline 6 & $\begin{array}{l}\text { Supplier tanggap terhadap } \\
\text { konsumen }\end{array}$ & Kualitas \\
\hline 7 & $\begin{array}{l}\text { Memiliki kapasitas produksi } \\
\text { yang memadai }\end{array}$ & Produksi \\
\hline 8 & $\begin{array}{l}\text { Memiliki jadwal produksi dan } \\
\text { realisasinya }\end{array}$ & Produksi \\
\hline 9 & Memiliki SOP dan check sheet & Produksi \\
\hline 10 & Memiliki perlengkapan safety & Produksi \\
\hline
\end{tabular}

\section{Sumber: data pengolahan}

Dari hasil kuesioner tahap pertama kemudian dibuat struktu hierarki sebagaimana gambar 2.

Data yang didapatkan dari kuesioner tersebut kemudian dibentuk ke dalam matriks perbandingan berpasangan pada level faktor (level 1) dari kuesioner dapat dilihat pada tabel 5 berikut:

Tabel 5. Matriks perbandingan berpasangan pada level kriteria

\begin{tabular}{|l|l|l|l|}
\hline $\begin{array}{l}\text { Pemilihan } \\
\text { supplier }\end{array}$ & Kualitas & Harga & Produksi \\
\hline Harga & 1 & 7 & 1 \\
\hline Harga & $1 / 7$ & 1 & $1 / 5$ \\
\hline Produksi & 1 & 5 & 1 \\
\hline
\end{tabular}

Hasil dari penilaian kuesioner yang diisi oleh para responden kemudian digabungkan untuk dihitung rataan geometrik (geometric mean). Berikut adalah hasil dari penggabungan penilaian untuk setiap kriteria (level 1) :

Tabel 6. Penggabungan penilaian level kriteria

\begin{tabular}{|c|l|l|l|l|}
\hline Level & Kriteria & \multicolumn{3}{|c|}{ Responden } \\
\cline { 3 - 5 } & & 1 & 2 & 3 \\
\hline \multirow{3}{*}{1} & Kualitas - Harga & 5 & 1 & 5 \\
\cline { 2 - 5 } & Harga - Produksi & $1 / 5$ & $1 / 5$ & $1 / 5$ \\
\cline { 2 - 5 } & Produksi - Kualitas & 1 & 1 & 1 \\
\hline
\end{tabular}

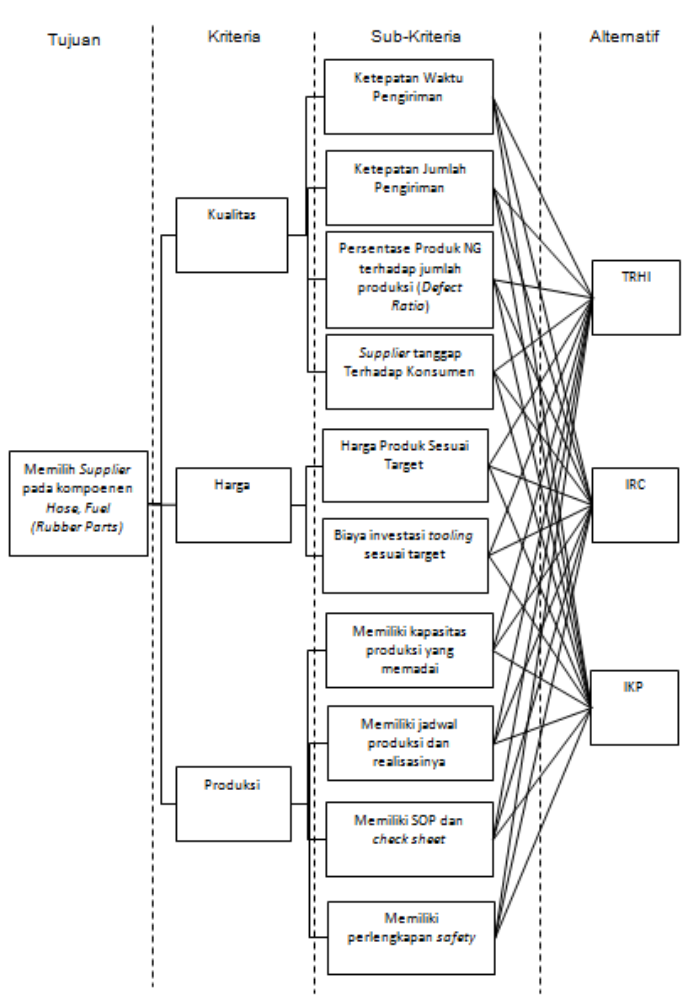

Gambar 2. Hirarki keputusan pemilihan supplier rubber parts 
Berikut adalah contoh perhitungan dengan geometric mean pada perbandingan pasangan kualitas-harga adalah : $R 1=5, R 2=1, R 3=5$. Dari ke tiga data tersebut kemudian dicari rataan geometriknya menggunakan persamaan:

$$
\begin{aligned}
& a_{i j}=\left(z_{1} \times z_{2} \times z_{3} \times \ldots \times z_{n}\right)^{1 / n} \\
& a=\left(z_{1} \times z_{2} \times z_{3} \times \ldots \times z_{n}\right)^{1 / n} \\
& a=(5 \times 1 \times 5)^{1 / 3} \\
& a=2,92
\end{aligned}
$$

Tabel 7. Geometric mean pada level kriteria

\begin{tabular}{|l|l|l|l|}
\hline Pemilihan supplier & Kualitas & Harga & Produksi \\
\hline Kualitas & 1.00 & 2.92 & 1.00 \\
\hline Harga & 0.34 & 1.00 & 0.20 \\
\hline Produksi & 1.00 & 5.00 & 1.00 \\
\hline
\end{tabular}

Selanjutnya, melakukan perhitungan Gometric Mean terhadap pasangan lain. Setelah mendapatkan perataan jawaban dengan Geometric Mean Theory maka pengujian berikutnya adalah konsistensi matriks.

Tabel 8. Total Geometric mean pada level kriteria

\begin{tabular}{|l|l|l|l|}
\hline Pemilihan supplier & Kualitas & Harga & Produksi \\
\hline Kualitas & 1.00 & 2.92 & 1.00 \\
\hline Harga & 0.34 & 1.00 & 0.20 \\
\hline Produksi & 1.00 & 5.00 & 1.00 \\
\hline Jumlah & 2.34 & 8.92 & 2.20 \\
\hline
\end{tabular}

Setelah itu, melakukan perhitungan normalisasi bobot penilaian perbandingan berpasangan antar faktor sebagai berikut :

Tabel 9. Normalisasi bobot penilaian pada level kriteria

\begin{tabular}{|l|l|l|l|c|c|}
\hline $\begin{array}{c}\text { Pemilihan } \\
\text { supplier }\end{array}$ & Kualitas & Harga & $\begin{array}{c}\text { Produk } \\
\text { si }\end{array}$ & $\begin{array}{c}\text { Jumla } \\
\mathrm{h}\end{array}$ & $\begin{array}{c}\mathrm{X} \\
\text { Bobot }\end{array}$ \\
\hline Kualitas & 0.43 & 0.33 & 0.45 & 1.21 & 0.40 \\
\hline Harga & 0.15 & 0.11 & 0.09 & 0.35 & 0.12 \\
\hline Produksi & 0.43 & 0.56 & 0.45 & 1.44 & 0.48 \\
\hline Jumlah & 1.00 & 1.00 & 1.00 & & 1.00 \\
\hline
\end{tabular}

Kemudian menghitung Consistency Ratio (CR). Apabila Consistency Ratio (CR) lebih kecil atau sama dengan $10 \%$ maka matriks telah memenuhi syarat konsistensi ( Saaty, 1993: 91) untuk menghitung Consistency Ratio (CR).

Hasil perhitungan ini dapat dilihat seperti berikut ini :

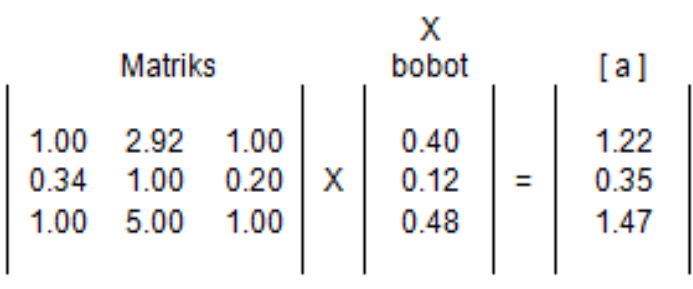

Dari hasil perhitungan, masing-masing baris pada kolom [a] dibagi dengan nilai ratarata ( $X$ bobot) untuk penentuan harga (D), pembagian tersebut adalah sebagai berikut:

$$
D=\left|\begin{array}{lll}
\frac{1.22}{0.40} & \frac{0.35}{0.12} & \frac{1.47}{0.48}
\end{array}\right|=\left|\begin{array}{lll}
3.04 & 3.01 & 3.05
\end{array}\right|
$$

Kemudian, dihitung nilai rata-rata dari hasil perhitungan di atas :

$\lambda_{\max }=\frac{\text { Jumlah elemen pada matriks bobot kriteria }}{\mathrm{N}}$

$\lambda_{\max }=\frac{9,10}{3}=3,03$

Dengan nilai konversi, nilai diatas disebut sebagai nilai Lamda maks $\left(\lambda_{\max }\right)$, dan Consistensy Indeks (Cl) dihitung dengan mengikuti rumus :

$C I=\frac{\lambda_{M A X}-N}{N-1}=\frac{3,03-3}{3-1}=0,02$

Untuk mendapatkan nilai Consistency Ratio (CR), bagi Consistensy Indeks (Cl) dengan Random Index (RI) lihat pada bab II, maka untuk matrik $3 \times 3$ atau $\mathrm{N}=3$, yaitu 0,58

$$
\begin{aligned}
& C R=\frac{C I}{R I} \\
& C R=\frac{0,02}{0,58}=0,028
\end{aligned}
$$

Nilai konsisitensi 0,028 atau sama dengan $2,8 \%$ dapat diterima karena lebih kecil dari $10 \%$ dan sesuai dengan syarat konsisitensi yang dikemukakan oleh Saaty.

Langkah yang sama digunakan untuk menghitung CR pada level sub-faktor hingga level alternatif tujuan. Pada level sub-faktor, penulis menggunakan bantuan software expert choice untuk menganalisis data hasil kuesioner.

Setelah melakukan pengujian Consistency Ratio (CR) setiap matriks perbandingan 
berpasangan, kemudian dilakukan pengujian Consistency Ratio of Hierarchy (CRH). Prinsipnya adalah dengan mengalikan semua nilai Consistency Index (CI) dengan bobot suatu kriteria yang menjadi acuan pada suatu matriks perbandingan berpasangan dan kemudian menjumlahkannya.

Suatu hirarki disebut konsisten bila nilai $\mathrm{CRH}$ tidak lebih dari 0,10 $(\mathrm{CRH} \leq 0,10)$.

Tabel 10. Nilai Consistency Index (Cl)

\begin{tabular}{|l|l|l|l|}
\hline Kriteria & $\mathrm{X}$ bobot & $\mathrm{Cl}$ & $\mathrm{CIH}$ \\
\hline $\begin{array}{l}\text { Pemilihan supplier } \\
\text { Rubber Parts }\end{array}$ & 1.00 & 0.016 & 0.016 \\
\hline Kualitas & 0.403 & 0.026 & 0.010 \\
\hline Harga & 0.116 & 0.000 & 0.000 \\
\hline Produksi & 0.481 & 0.017 & 0.008 \\
\hline Total & 0.035 \\
\hline
\end{tabular}

Tabel 11. Random Index of Hierarchy (RIH)

\begin{tabular}{|l|l|l|l|}
\hline Kriteria & $\mathrm{X}$ bobot & $\mathrm{RI}$ & $\mathrm{RIH}$ \\
\hline $\begin{array}{l}\text { Pemilihan supplier } \\
\text { Rubber Parts }\end{array}$ & 1.00 & 0.580 & 0.058 \\
\hline Kualitas & 0.403 & 0.900 & 0.363 \\
\hline Harga & 0.116 & 0.000 & 0.000 \\
\hline Produksi & 0.481 & 0.900 & 0.433 \\
\hline Total & 1.375 \\
\hline
\end{tabular}

Setelah didapat $\mathrm{CIH}$ dan $\mathrm{RIH}$ maka dapat diketahui Consistency Ratio of Hierarchy $(\mathrm{CRH})$ perhitungannya sebagai berikut :

$$
C R H=\frac{C I H}{R I H}=\frac{0,035}{1,375}=0,025
$$

Nilai Consistency Ratio of Hierarchy $(\mathrm{CRH})$ sebesar 0,025 lebih kecil dari 0,1, maka dapat dikatakan bahwa hirarki yang dibuat telah konsisten karena sesuai dengan syarat yang di kemukakan Saaty.

Setelah data yang diperoleh telah dinyatakan konsisten, maka dapat ditentukan urutan alternatif tujuan sesuai dengan bobot prioritas.
Tabel 12. Urutan alternatif tujuan sesuai bobot prioritas

\begin{tabular}{|c|c|c|c|c|c|}
\hline Kriteris & Bobot & Sub-kritenis & $\begin{array}{l}\text { Bobot } \\
\text { Sub- } \\
\text { knteris }\end{array}$ & $\begin{array}{l}\text { Bobot } \\
\text { Globsl }\end{array}$ & $\begin{array}{l}\text { Unutan } \\
\text { Priorits: }\end{array}$ \\
\hline \multirow{4}{*}{ Kugitis } & \multirow{4}{*}{0.403} & Ketepatan Waktu Pengiriman & 0.41 & 0.163 & 2 \\
\hline & & \begin{tabular}{|l|} 
Ketepatan Jumlah Pengiriman \\
\end{tabular} & 0.23 & 0.094 & 5 \\
\hline & & \begin{tabular}{|l} 
Persentsge Produk NG terhsdgp \\
jumlsh produks (Defectratio)
\end{tabular} & 0.16 & 0.064 & 9 \\
\hline & & \begin{tabular}{|l|}
$\begin{array}{l}\text { Suppliertangggp Terhsdgp } \\
\text { Konsumen }\end{array}$ \\
\end{tabular} & 0.20 & 0.082 & 7 \\
\hline \multirow{2}{*}{ Hargs } & \multirow{2}{*}{0.116} & Harga ProdukSesuai Target & 0.78 & 0.091 & 6 \\
\hline & & Bisys investasi toolingsesusitarget & 0.22 & 0.026 & 10 \\
\hline \multirow{4}{*}{ Produks } & \multirow{4}{*}{0.481} & $\begin{array}{l}\text { Memilkikspasitas produksi yang } \\
\text { memadgi }\end{array}$ & 0.22 & 0.105 & 4 \\
\hline & & $\begin{array}{l}\text { Memilikjijodwal produksidan } \\
\text { realisasinya }\end{array}$ & 0.39 & 0.188 & 1 \\
\hline & & Memiliki SOP dan checksheet & 0.23 & 0.109 & 3 \\
\hline & & Memilki perlengkapan safely & 0.16 & 0.078 & 8 \\
\hline
\end{tabular}

Sumber: Pengolahandats

Tahap terakhir adalah menghitung bobot prioritas pemilihan alternatif supplier, yang juga dihitung bobot lokal dan bobot globalnya, yang merupakan perkalian antara bobot lokal supplier dengan bobot yang ada di level atasnya.

Tabel 13. Hasil perhitungan bobot prioritas pemilihan alternative

\begin{tabular}{|c|c|c|c|c|}
\hline \multirow{2}{*}{ Sub-kriteris } & \multirow{2}{*}{$\begin{array}{l}\text { Bobot } \\
\text { Global }\end{array}$} & \multicolumn{3}{|c|}{ Bobot Alternatfi supplier } \\
\hline & & TRHA & 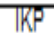 & $\mathbb{R} C$ \\
\hline Ketepatan Waktu Pengiriman & 0.163 & 0.68 & 0.12 & 0.20 \\
\hline Ketepstan Jumlgh Pengiriman & 0.094 & 0.68 & 0.12 & 0.20 \\
\hline $\begin{array}{l}\text { Persentage Produk NG terhadgo jumlah } \\
\text { produks (Defed Ratio) }\end{array}$ & 0.064 & 0.71 & 0.12 & 0.17 \\
\hline Suppliertanggesp Terhadgp Konsumen & 0.082 & 0.18 & 0.42 & 0.40 \\
\hline Harga ProdukSesugi Target & 0.091 & 0.11 & 0.70 & 0.20 \\
\hline Biays investasi tooling sesusi target & 0.026 & 0.13 & 0.67 & 0.21 \\
\hline Memilikikapastas produks yang memgdgi & 0.105 & 0.64 & 0.18 & 0.18 \\
\hline Memilikj jadwal produksi dgn resisasinys & 0.188 & 0.50 & 0.22 & 0.28 \\
\hline MemilkiSOP dan checksheet & 0.109 & 0.50 & 0.22 & 0.28 \\
\hline Memiliki perlengkapan safity & 0.078 & 0.65 & 0.14 & 0.20 \\
\hline
\end{tabular}

Sumber: Pengolahan Data

Untuk mendapatkan bobot alternatif, kalikan bobot global dengan nilai masingmasing alternatif, sehingga diperolah sebagai berikut: 
Tabel 14. Hasil perhitungan bobot global

\begin{tabular}{|c|c|c|c|}
\hline \multirow{2}{*}{ Sub-kriteria } & \multicolumn{3}{|c|}{ Bobot GlobalAlternatf Supplier } \\
\hline & TRHI & $\mathrm{IKP}$ & $\mathrm{IRC}$ \\
\hline Ketepatan Waktu Pengiriman & 0.11 & 0.02 & 0.03 \\
\hline Ketepatan Jumlah Pengiriman & 0.06 & 0.01 & 0.02 \\
\hline $\begin{array}{l}\text { Persentage Produk NG terhadgp jumlah } \\
\text { produksi (Defect Ratio) }\end{array}$ & 0.05 & 0.01 & 0.01 \\
\hline Suppliertanggap Terhadgp Konsumen & 0.01 & 0.03 & 0.03 \\
\hline Harga ProdukSesusi Target & 0.01 & 0.06 & 0.02 \\
\hline Bigys investasi tooling sesusi target & 0.00 & 0.02 & 0.01 \\
\hline Memiliki kapasitas produksi yang memadai & 0.07 & 0.02 & 0.02 \\
\hline Memilikj jadwal produksi dan realisasinya & 0.09 & 0.04 & 0.05 \\
\hline Memilki SOP dan checksheet & 0.06 & 0.02 & 0.03 \\
\hline Memilki perlengkapan safely & 0.05 & 0.01 & 0.02 \\
\hline Jumlah & 0.516 & 0.248 & 0.236 \\
\hline
\end{tabular}

Secara global prioritas pertama untuk pemilihan supplier hose fuel adalah supplier TRHI dengan bobot 0,516 kemudian supplier IKP dengan bobot 0,248 dan terakhir supplier IRC dengan bobot 0,236.

Analisis sensitivitas dilakukan pada bobot prioritas dari kriteria keputusan, yang dapat terjadi karena adanya perubahan kebijaksanaan sehingga pembuat keputusan mengubah penialaiannya.

Model analisis AHP dapat digunakan untuk mengetahui kecenderungan pemihan alternatif tujuan berdasarkan perubahan pada setiap kriteria pemilihan supplier. Berikut adalah gambar Dinamic Sensitivity dari Alternatif Tujuan

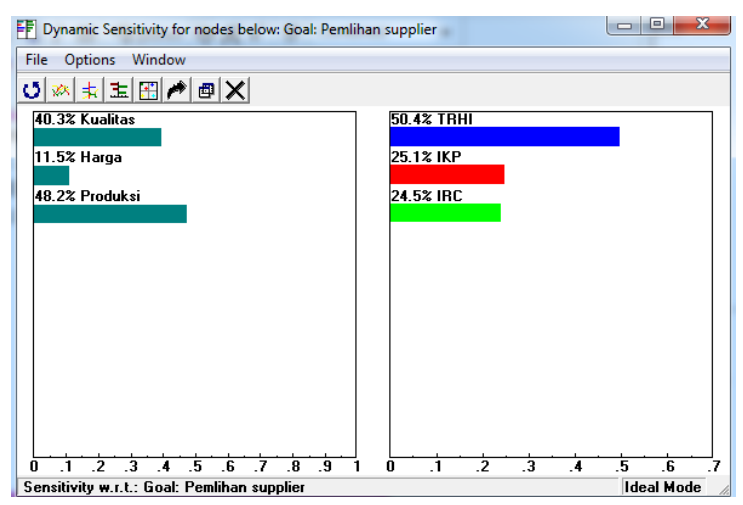

Gambar 3. Dinamic Sensitivity dari Alternatif Tujuan

Berikut adalah gambar Performance Sensitivity dari Alternatif Tujuan

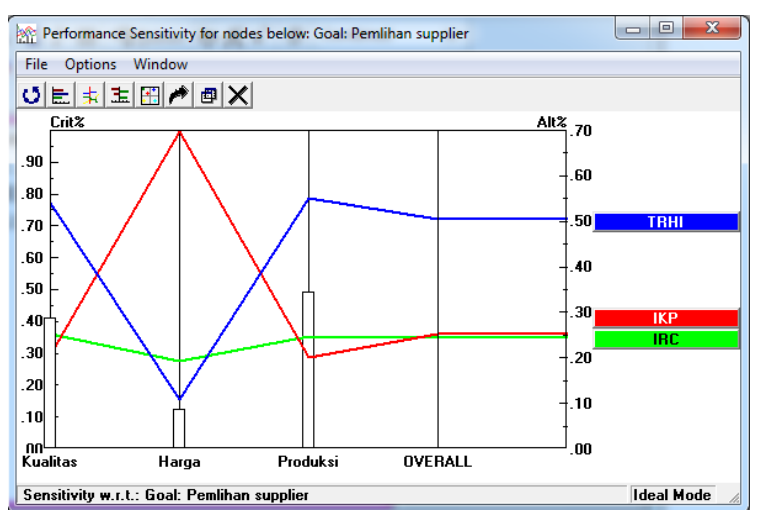

Gambar 4. Performance Sensitivity dari Alternatif Tujuan

Setelah itu, dari masing-masing faktor dinaikan atau diturunkan tergantung dari kebijakan manajemen perusahaan, maka dilakukan analisa terhadap faktor kualitas, harga, dan produksi.

Berikut perubahan bobot pada kriteria kualitas dinaikan $10 \%$

Tabel 15. Hasil perubahan bobot kriteria kualitas

\begin{tabular}{|c|c|c|c|c|c|}
\hline \multirow[t]{2}{*}{ Kriteria } & \multirow{2}{*}{$\begin{array}{c}\text { Bobot } \\
\text { Sekarang }\end{array}$} & \multicolumn{3}{|c|}{$\begin{array}{l}\text { Peningkatan Prioritas pada Kriteria } \\
\text { Kualitas }\end{array}$} & \multirow{2}{*}{$\begin{array}{c}\text { Perubahan } \\
\text { Bobot }\end{array}$} \\
\hline & & $+10 \%$ & $+20 \%$ & $+30 \%$ & \\
\hline Kualitas & $40.30 \%$ & $50.30 \%$ & $60.30 \%$ & $70.30 \%$ & $10 \%$ \\
\hline Harga & $11.50 \%$ & $9.60 \%$ & $7.70 \%$ & $5.80 \%$ & $-1.90 \%$ \\
\hline Produksi & $48.20 \%$ & $40.00 \%$ & $31.80 \%$ & $23.60 \%$ & $-8.20 \%$ \\
\hline \multicolumn{6}{|l|}{ Supplier } \\
\hline TRHI & $50.40 \%$ & $51 \%$ & $51.60 \%$ & $52.20 \%$ & $0.60 \%$ \\
\hline IKP & $24.50 \%$ & $24.40 \%$ & $23.70 \%$ & $23.00 \%$ & $-0.70 \%$ \\
\hline IRC & $25.10 \%$ & $24.60 \%$ & $24.70 \%$ & $24.80 \%$ & $0.10 \%$ \\
\hline
\end{tabular}

Berikut perubahan bobot pada kriteria harga dinaikan $10 \%$.

Tabel 16. Hasil perubahan bobot kriteria harga

\begin{tabular}{|c|c|c|c|c|c|}
\hline \multirow{2}{*}{ Kriteris } & \multirow{2}{*}{$\begin{array}{c}\text { Bobot } \\
\text { Sekgrang }\end{array}$} & \multicolumn{3}{|c|}{ Peningkstan Prioritas pada Kriteria Harga } & \multirow{2}{*}{$\begin{array}{c}\text { Perubahan } \\
\text { Bobot }\end{array}$} \\
\hline & & $10 \%$ & $20 \%$ & $30 \%$ & \\
\hline Kusiltas & $40.30 \%$ & $35.90 \%$ & $31.50 \%$ & $27.10 \%$ & $-4 \%$ \\
\hline Hargs & $11.50 \%$ & $21.40 \%$ & $31.30 \%$ & $41.20 \%$ & $10 \%$ \\
\hline Produksi & $48.20 \%$ & $42.80 \%$ & $37.40 \%$ & $32.00 \%$ & $.5 \%$ \\
\hline \multicolumn{6}{|l|}{ Supplier } \\
\hline TRHI & $50.40 \%$ & $45.30 \%$ & $40.20 \%$ & $35.10 \%$ & $-5.10 \%$ \\
\hline IKP & $25.10 \%$ & $30.90 \%$ & $36.70 \%$ & $42.50 \%$ & $5.80 \%$ \\
\hline IRC & $24.50 \%$ & $23.80 \%$ & $23.10 \%$ & $22.40 \%$ & $-0.70 \%$ \\
\hline
\end{tabular}

Berikut perubahan bobot pada kriteria produksi dinaikan dan diturunkan $10 \%$. 
Tabel 17. Hasil perubahan bobot kriteria kualitas

\begin{tabular}{|c|c|c|c|c|c|c|c|}
\hline \multirow{2}{*}{$\begin{array}{l}\text { Kriteria } \\
\text { Kualitas } \\
\end{array}$} & \multirow{2}{*}{$\begin{array}{c}\begin{array}{c}\text { Bobot } \\
\text { Sekgrang }\end{array} \\
40,30 \% \\
\end{array}$} & \multicolumn{2}{|c|}{$\begin{array}{c}\text { Peningkstan } \\
\text { Prioritas pads } \\
\text { Kriteris Produksi }\end{array}$} & \multirow{2}{*}{$\begin{array}{c}\begin{array}{c}\text { Perubahan } \\
\text { Bobot }\end{array} \\
7,90 \% \\
\end{array}$} & \multicolumn{2}{|c|}{$\begin{array}{c}\text { Penurungn Priortas } \\
\text { pada Kriteris } \\
\text { Produksi } \\
\end{array}$} & \multirow{2}{*}{$\begin{array}{c}\begin{array}{c}\text { Perubahan } \\
\text { Bobot }\end{array} \\
7,40 \%\end{array}$} \\
\hline & & $32,40 \%$ & $24,50 \%$ & & $47,70 \%$ & $55,10 \%$ & \\
\hline Harga & $11,50 \%$ & $9,30 \%$ & $7,10 \%$ & $-2,20 \%$ & $13,60 \%$ & $15,70 \%$ & $2,10 \%$ \\
\hline Produksi & $48,20 \%$ & $58,30 \%$ & $68,40 \%$ & $10,10 \%$ & $38,70 \%$ & $29,20 \%$ & $9,50 \%$ \\
\hline \multicolumn{8}{|l|}{ Supplier } \\
\hline TRHI & $50,40 \%$ & $51,30 \%$ & $52,20 \%$ & $0,90 \%$ & $49,50 \%$ & $48,60 \%$ & $0,90 \%$ \\
\hline IKP & $25,10 \%$ & $24,10 \%$ & $23,10 \%$ & $-1,00 \%$ & $26,10 \%$ & $27,10 \%$ & $1,00 \%$ \\
\hline 5 & $24,50 \%$ & $24,00 \%$ & $24,70 \%$ & $0,10 \%$ & $24,40 \%$ & $24,30 \%$ & $0,10 \%$ \\
\hline
\end{tabular}

Sumber: pengolahan data (expert choice)

Dari analisis sensitvitas pada kriteria, diketahui bahwa perubahan kebijakan dari kriteria produksi dan kualitas, tidak akan mengubah supplier yang terpilih, yaitu TRHI, namun ketika kebijakan faktor harga dinaikan lebih dari 30\%, maka supplier IKP yang terpilih. Bagaimana pun keadaanya supplier TRHI mempunyai bobot diatas $50 \%$ sehingga perubahan kebijakan kriteria yang tidak signifikan tidak merubah TRHI sebagai supplier yang terpilih.

\section{KESIMPULAN DAN SARAN}

Ada beberapa faktor yang mempengaruhi keputusan pemilihan supplier pada komponen hose fuel ada tiga faktor yaitu faktor kualitas dengan bobot 0,403 yang terdiri dari empat subfaktor yaitu ketepatan waktu pengiriman 0,41 , ketepatan jumlah pengiriman 0,23 , Persentase Produk NG terhadap jumlah produksi (defect ratio) 0,16 , dan supplier tanggap terhadap konsumen 0,2 . Faktor yang kedua yaitu faktor harga dengan bobot 0,116 yang terdiri dari dua sub-faktor yaitu harga produk sesuai target 0,78 dan Biaya investasi tooling sesuai target 0,22. Dan faktor yang terakhir yaitu faktor produksi dengan bobot tertinggi 0,481 yang terdiri dari empat sub-faktor yaitu memiliki kapasitas yang memadai 0,22 , memiliki jadwal produksi dan realisasinya 0,39 , memiliki SOP dan check sheet 0,23 serta memliki perlengkapan safety 0,16 .

Dalam pemilihan supplier sebaiknya dilakukan keterlibatan beberapa bagian terkait tidak hanya bagian purchasing, seperti bagian enginering, quality dan produksi.

Penelitian yang dilakukan masih belum sempurna. Masih banyak hal yang dapat dikembangkan dan diperbaiki untuk menjalankan penelitian ini. Untuk penelitian berikutnya dapat menggunakan metode 102
TOPSIS, ANP, dan metode lainnya agar pemilihan supplier benar-benar ideal dapat tercapai. Selain itu, perlu diteliti untuk semua supplier yang terpilih pada produk yang sudah berjalan agar efisiensi perusahaan dapat tercapai

\section{DAFTAR PUSTAKA}

Alfian, Ignatius A. Sandy, Hanif Fathurahman (2013). Penggunaan Metode Analytic Network Process (ANP) dalam Pemilihan Supplier Bahan Baku Kertas pada PT Mangle Panglipur, Jurnal Rekayasa Sistem Industri Vol. 2, No.1.

Chopra, S., Meindle, P., (2001). Supply Chain Management : Strategy, Planning, and Operation. Prentice Hall,

D. Rimantho, B.Cahyadi. (2016). "Six Sigma MethodApproach in the Prevention of Occupational Accidents on the Solid Waste Collector in South Jakarta." ARPN Journal of Engineering and Applied Sciences, Vol.11(16), pp. 10014-22.

D. Rimantho, T.A.Rahman, B.Cahyadi., (2017). "Application of six sigma and AHP in analysis of variable lead time calibration process instrumentation". In AIP Conference Proceedings, Vol.1813(1), 040004, http://dx.doi.org/10.1063/1.4975969

Heywood, J, Brian., (2015). The Outsourcing Dilemma: The Search for Competitiveness, Prentice Hall.

Lin, Tseng Cheng., Wen, Wu Yen., Ting, Yu Ling,. (2007). The Evaluation of Decision Factors in Logistic Outsourcing, International Conference on Logistics, Shipping and Port Management.

Pujawan, I Nyoman. (2005). Supply Chain Management, Guna Widya, Surabaya.

Randall, P., Brown, L., Deschaine, L., Dimarzio, J., Kaiser, G., Vierow, J., (2004). Application of the analytic hierarchy process to compare alternatives for the long term management of surplus mercury. J. Environ. Manage. 71, 3543.

Rimantho, D., Cahyadi B., Dermawan D., (2015). Application Analytic Hierarchy Process (AHP) by utilizing the Expert Choice as a tool in decision-making: a case study of e-waste management in Surabaya, Indonesia, Terdapat pada: https://www.researchgate.net/publication/27 9959950 APPLICATION ANALYTIC HIER ARCHY PROCESS AHP A CASE STUD Y OF EWASTE MANAGEMENT IN SUR ABAYA INDONESIA? ev=prf pub (diakses pada: 25 April 2015).

Singh, Ravendra et al., (2012). Supplier Selection By Technique of Order Preference by Similaruty to Ideal Solution (TOPSIS) 
Method for Automotive Industry. International Journal of Advance Technology \& Engineering Research (IJATER).

Saaty T. L., (1980). The Analytical Hierarchy Process: Planning, Priority Setting, Resource Allocation, McGraw-Hill Book Company, United States of America.

Saaty, Thomas L. \& Luis G. Vargas. (1993). Models, Methods, Concept \& Aplications of the Analytic Hierarchy Process. Internationel Series in Operations Research \& Management Science. Second Edition. Springer. New York.

Suryadi, Kadarsah, Ali Ramdhani., (2002). Sistem Pendukung Keputusan : Suatu Wacana Struktural Idealisasi dan Implementasi Konsep Pengambilan Keputusan. Bandung : PT.Remaja Rosdakarya.

Wang, G., Qin, L., Li, G., Chen, L., (2009). Landfill site selection using spatial information technologies and AHP: a case study in Beijing, China. J. Environ. Manage. 90, 2414-2421. 
Halaman ini sengaja dikosongkan

This page is intentionally left blank 